\title{
COUNTY GOVERNMENT REFORM EFFORTS IN MISSISSIPPI
}

\author{
Martin Wiseman \\ (Stennis Institute of Government, \\ Mississippi State University)
}

\section{Introduction}

County government reform has become the subject of great interest today in Mississippi. Recent incidents of illegalities and irregularities in the conduct of county government have brought forth calls for reform from various sectors and these reform demands have been met by equally enthusiastic opposition to any action which might alter the current relationship that rural citizens have with county officials who represent them.

Opposition by county officials and a large segment of the rural electorate quickly evaporates any notion that reform will be easy. Reform efforts generally create controversy because the affected constituents believe their fundamental rights to be governed as they choose will be abridged.

Those with vested interests seek to preserve the status quo, typically perceived by reformists to be an outdated system of county government. Reformists, on the other hand, consistently miss the mark by advocating theoretical models or approaches to improve county management with little attention to whether the reform will improve services to the citizens of the county. Acceptance of reform depends largely upon whether local officials and citizens are convinced that pre-reform, traditional types and levels of service will be at least maintained if not improved.

The traditional form of county government advocated as the best to provide countywide service in Mississippi is called the "Unit System." The Unit System is a form of government characterized by centralized policymaking and management of governmental services and functions provided by an elected board of county officials called supervisors. Budgeting, personnel administration, public works, and other county services and functions are provided without regard to demarcation of electoral districts of elected county officials.

This paper argues that reform policies, regardless of their obvious payoffs, will not be successful in a rural setting without careful attention to the socio-political environment. Administrative and structural models 
which work in one setting may not easily transfer to another.

Although the focus of this article is on county government reform in Mississippi, the substantive content goes beyond the narrow interest in reform in this rural state. It takes into account generic structural problems that exist and the problems created by efforts to accomplish reform in a rural conservative environment. Basic theories about the relationship between socio-political cultures and local governmental operations are reviewed, and the sources of resistance to change in Mississippi are identified and explored to better understand the circumstances that have brought county government reform to the top of the state's political agenda. Also, it analyzes county officials' and constituents' reactions to the demand for change which will revise existing county government structure.

\section{Theoretical Foundations: The Role of Socio-Political Linkages in Rural and Local Government}

In a classical sense the debate over reform of county government in Mississippi has been characterized by the desires of rural citizens and the county officials who represent them to preserve a traditional form of rural democracy on the one hand and the efforts of those who advocate change in the form of consolidated and centralized management on the other. This is true with regard to the general notion of reform itself as well as to the mechanics by which specific reforms are achieved.

Indeed, elements of Jeffersonian and Jacksonian democracy can be seen in this modern day controversy. The Jeffersonian affinity for the rural life as an antidote to the concentration and corruption of power in the hands of the moneyed aristocracy led him to laud the virtues of a basic and understandable local government (Schlesinger, 1953). Jackson revived and broadened the focus of Jeffersonian ideals by including many who had previously been afforded little opportunity to meaningfully exercise citizenship (Schlesinger, 1953). The Jeffersonian and Jacksonian advocacy of limitations of the powers of big government and wide participation of citizens led to the conclusion that the best vehicle for self-government is local government (Blau, 1954). These same sentiments have been expressed by citizens of rural Mississippi counties in the face of various reform proposals which they see as threatening to the constituent/official relationship to which they have long been accustomed. This relationship is based on the feeling of rural citizens that they have a proven means of holding their representatives (county supervisors) accountable for their responsiveness or lack thereof. Accountability, in this sense, is assured 
because those who hold office wish to continue in office. Those who wish to govern make decisions they believe to be in accord with voter preferences (Prewitt, 1970). Such a process of accountability contributes to an explanation of the active resistance by county supervisors to any change which might alter the traditional constituent official relationship.

Reform efforts in such an environment must deal with the need for governmental structures to be in congruence with local socio-economic values and experiences (Reagan, 1968). This emphasis on the linkages of social factors to structural aspects of local government may be manifested in leader's perceptions (Hansen, 1978). Thus, citizen participation is a major factor linking citizen preferences to public policy (Verba and Nie, 1972). David Morgan (1973) further elaborated this relationship in stating that in grass-roots suburbia, local officials ordinarily reflect the general social and economic background of those they represent. He further suggests that people who share residence in the same suburban sociopolitical area may indeed share uniform values. Bonds of kinship and friendship within rural communities are strengthened by community attachment (Kasarda and Janowitz,1974). Cultural traditions produced by such attachments impact political institutions and associations. Furthermore, these attachments become so strong that citizens in rural areas want to preserve the status quo (Redfield, 1955). Thus, rural communities possess homogeneity, conditions in which activities and states of mind are much alike (Redfield, 1955). Each generation carries forward these conditions of homogeneity from the preceding one. Thus, change occurs slowly (Redfield, 1955).

The nature of this unique political environment becomes even more interesting when a distinction is made between municipalities and counties. While both are considered to be similar in that they are both local governmental units, the reality is that they each play a different role and they go about their work in different ways. Counties govern territory without regard to the numbers of people within their boundaries. They are a means to administer state and federal programs at the local level and they are a vehicle for representation for rural citizens. Municipalities, on the other hand, come into being as a result of citizens gathering together in the same locale and acting on the need and the capability of providing themselves with an array of corporate services. This distinction is important in any philosophical discussion of counties and municipalities as comparable local government entities. Municipalities are demand driven in the services they provide. They owe this to the fact that their coming into being was a result of a perceived need of citizens to provide them- 
selves with basic amenities such as police and fire protection, sanitation, and education which would have been largely unaffordable otherwise.

County governments, particularly those in predominantly rural areas, came into existence as territorial mechanisms to enable rural citizens a means of transacting business with the state government. Demands for more and better services have increased at the county level, but they are usually for services that would enhance rural life, such as better farm to market roads, rural water systems, and rural emergency services. These needs cause rural citizens to place a greater emphasis on the established constituent/official relationship as a mechanism of representation. The characteristics of such an arrangement have been summarized quite effectively in The Forgotten Governments by Marando and Thomas (1977).

\begin{abstract}
Although many counties are sufficiently populated to be classed as urban or semi-urban, a majority of them are primarily rural or small town in composition and retain patterns of government that were created by an agrarian society. Counties provide civic links between rural citizens and the outside world. County government continues to reflect no little acceptance of the idea of performance by laymen or amateurs rather than by experts or professionals, unless politicians [can] be classed as professionals (Grant and Nixon, 1968 in Marando and Thomas, 1977, p. 1).
\end{abstract}

According to Marando and Thomas (1977) we have established fragmented authorities in various units and levels of government which have resulted in policy solutions devised as much to disperse governmental authority and protect the integrity of theway the system operates as to solve public problems. Thus, in the case of the research documented here, it may be maintained that rural citizens perceive reform efforts more in terms of threats to the system than as opportunities for better service delive $\mathrm{y}$. The fact that these perceived threats have come from outside of the so-io-political environment in which county government generally operates serves to consolidate sentiments of rural county citizens against any change.

\title{
Impediments to Reform
}

\section{Value of Tradition}

Since 1890 , by tradition later reaffirmed legislatively, the fivemember county boards of supervisors have assumed virtually autonomous authority over road and bridge operations of their respective districts, 
called "beats," in Mississippi. This prevents a countywide approach to infrastructure planning, construction and maintenance, and to other county services. This five-way fragmentation of the management of county infrastructure results in a lessening of a countywide perspective in addressing county affairs. Equipment to be used in a particular beat is purchased solely at the desire of the supervisor elected by citizens within that specific beat. Personnel are hired, fired, and remunerated at the wage level of each respective supervisor by beat. Material and consumable are purchased, stored, and dispensed separately in each of the five beats based purely upon the desires of the beat's supervisor and the budgetary capacity of the beat. In short, five small governmental entities, all performing the same functions, exist and operate autonomously within the legal and geographic confines of a single county.

\section{Ballot Box Service}

Boards of supervisors have not operated as unified countywide policymaking bodies; rather, their members have become individual executives as well as policy makers. Not only are county supervisors the legislative representatives of their respective constituencies in county government, they also personally perform the work of the county in each beat. This role is perceived by incumbent supervisors as central to their success at the ballot box. Therefore, a premium is placed on the supervisor's ability to keep individual citizens of his beat satisfied rather than to foster the well being of the entire county. Any system of reform which changes this equation meets with immediate skepticism on the part of supervisors. The notion that such a system might be mandated by the legislature intensifies measurably the resistance to reform. Only reform that is subjected to the individual's exercise of preference at the ballot box in each county has any prospect of approval. Only this method of introducing change is consistent with the tradition that has sustained the operation of the beat system.

\section{Constituency Opposition to Change}

The attitude of the voting public in Mississippi may be characterized as resistant. Constituents who are most vocally opposed to reform are largely residents of rural areas heavilydependent on the ability of the supervisor in their beat to attend to their individual needs and to fulfill their supervisorial responsibilities. As long as roads are easily passable, 
bridges are easily crossable, solid waste does not become an eyesore, and quick response to some specific problem can be gained from a call to the supervisor, county government is perceived as being responsive and these rural voters are fairly satisfied. So, where services seem to be provided satisfactorily, voters are reluctant to "rock the boat." However, when the personal relationship between a supervisor and his constituency is removed, this perception of satisfactory service provision and the feelings of satisfaction begins to breakdown. This indicates some level of dissatisfaction with the overall system on the part of the citizenry. This fact was born out in research conducted in the spring of 1986 in a study of 427 residents, primarily from rural unincorporated communities, located in four counties in Mississippi from the Tennessee line in the north of the state to the Louisiana line in the south. approximately 54 percent of the respondents surveyed were black; 46 percent were white. Questionnaires were administered on a non-random basis to residents contained on rosters of rural community organizations (Wiseman, 1986). Questions were asked about rural citizens' perceptions of local governments and local government officials. Table 1 summarizes some of the results.

These results reveal a measure of citizen ambivalence toward largely rural communities and county government. Items 1,2 , and 3 indicate the intensity of the desire of rural citizens, as a community, to have officials aware of their needs and to be influential in county government operations. Community identity becomes even more apparent by the responses (items 4 and 5) which illustrate that rural citizens' expectations of county government performance reflect community self interest without great regard for other areas of the county. Item 6 indicates a community-based awareness of the value of local government officials that is apparent among the respo dents. However, the responses reveal a more personalized dissatisfaction with local government officials as individual policy makers or policy implementors (items 7 through 10). Of pivotal importance is the fact that 50 percent of the respondents are willing to consider consolidation of county services. But, it is not clear what the motivation is for this position. It is reasonable for this position to be taken if the rural communities believe they could realize public service improvements as a result of consolidation.

It is of additional interest to note that analysis revealed no significant differences between black rural community residents and white rural community residents in their feelings toward their communities and the officials who represent them (Wiseman, 1986). 


\section{Table 1. Attitudes of Rural Citizens Toward Local Communities and Local Government Officials}

1. Important for officials to know what community thinks

2. Elect Supervisor to help the community

3. It is importnat to meet with officials as a community

4. Community not as important as whole county

Agree Disagree "No Opinion $96.7 \%$

$1.0 \%$

$2.4 \%$

$97.4 \%$

$1.0 \%$

$2.1 \%$ wholecounty

5. All communities are alike

$22.3 \%$

$60.3 \%$

$7.3 \%$

6. Elected officials are helpful to this community

$64.8 \%$

$19.7 \%$

$15.4 \%$

7. Officials don't care what I think

$50.0 \%$

$34.2 \%$

$15.8 \%$

8. Officials don't represent the people's interest

$48.0 \%$

$37.0 \%$

$14.1 \%$

9. My supervisor never does what

$45.5 \%$

$40.4 \%$

$14.1 \%$

I want

10. The only time we see elected officials is when they are looking for votes

11. Would favor consolidation for

better services

$50.0 \%$

$17.9 \%$

$32.1 \%$

$62.4 \%$

$27.9 \%$

$9.4 \%$

The ambivalence of citizens to local officials and their responsiveness to them as a community provides a platform for reform if the proper stimulus were provided and if such reforms could be viewed by rural citizens as congruent with their ideas regarding the proper constituent/ official relationship. 


\section{Impetus for Reform}

\section{Mandated State Level Reform}

In January of 1984, newly elected State Auditor Ray Mabus took office vowing that "business as usual at the county level would hereafter be a risky proposition." Mabus ran against the traditional line of succession to the office of State Auditor and, as Auditor, disrupted the traditional cordial relationship that had existed between the Department of Audit and county governments in Mississippi.

In county after county, Mabus investigated instances of financial irregularity and reported them in dramatic fashion via the news media. In addition to cases that reflected outright criminal activity, many cases revealed a mere lack of efficiency in county government financial operations. These revelations produced charges that county government in Mississippi was outdated, lacked appropriate checks and balances, and was wasteful in its efforts to provide local government services. The new State Auditor claimed to have produced proof for what many interested in county government reform had suspected all along--that county government in Mississippi was fraught with structural and managerial problems. Ma' us maintained that solutions to these problems were to be found in the structural reform of county government from the "beat system" to the "unit system." To strengthen his reform thesis and to engender public support for change, the fortuitous events of federal indictments swept across several counties.

\section{"Operation Pretense"}

n an endeavor known as "Operation Pretense" the Federal Bureau of Investigation (FBI) committed manpower and resources to determine the extent to which county officials operating under the beast system had used the system for personal gain. Posing as equipment dealers from a fictitious heavy equipment company, FBI officials documented over a four-year period widespread illegalities in the purchase of equipment by county officials. A number of indictments, guilty pleas, and convictions resulted from this operation. Of those indicted, 57 were county supervisors, three were equipment dealers, and one was a foreman on a county supervisor's staff. Charges ranged from mail fraud to bribery to extortion to collusion. Public concern generated during Mabus' tenure as State Auditor peaked in the spring of 1988 during his first year as governor. Demand for reform is 
prevalent in the state, and it has permeated state government politics. Mabus' victory as the Democratic Governor of Mississippi demonstrated that the magnitude of the reform trust. County government reform remained a key agenda item of the governor. The result of the reform initiative was the passage of the County Government Reform Act (CGRA) of 1988.

\section{Key Statewide Interest Groups}

Mississippi Economic Council (MEC), has been one of the key parties at interest for government reform in the state. For more than two decades it has advocated a change from the beat system to the county unit system. The consequence of the FBI investigation has served, for some, as an illustration of how the long held MEC position, in retrospect, appears to have been visionary. As a reform-minded organization, the MEC has advocated a concrete set of government changes designed to introduce sophisticated management practices to county governments. It took an active role in advocating the passage of the County Government Reform Act of 1988.

\section{The County Supervisors}

County supervisors have viewed reform initiatives from both a selfinterest and self-protective posture. Their posture reflects their feelings that they have been viewed as "scapegoat" for the governor's political ambitions and that county governments have been made victims of federal and state intervention into local affairs. These tow approaches of county supervisors are instrumental. They can and were used to obscure the real issue of the inadequacy of governmental structure and managerial capacity. The need to reform and restructure county government operations was seen by many county supervisors as a way of severing the close ties between supervisors and their constituents.

\section{Citizen Constituents}

Have local constituencies accepted the need for reform? Recent election results, including the statewide, county-by-county referendum on the county unit system in November, 1988, leave this question partially answered. In local elections some indicted county supervisors either won reelection or lost very narrowly. In other counties, supervisors who had 
voluntarily advocated adoption of the unit system were beaten rather soundly. There were, however, any instances where pro-reform candidates won. What is clear is that local citizens are concerned about the current status of their rural communities and the extent to which, they are able to determine that status. They desire continued service at least at current levels and hopefully at higher levels. Many are fearful of losing the "closeness" of government characterized by George Blair in his "grassroots" government (Blair, 1986).

Citizen reluctance to change the "status quo" may be a signal to county supervisors that they should take comfort in their reluctance. If the rural citizenry has displayed previously trust in the parochial "beat system", they also have begun to develop a significant level of distrust because of the actions of those officials who have placed the "beat system" of government in jeopardy.

What are the possible solutions? Solutions to this complex web of individual feelings about governance, public services, and government structures lie in the simultaneous process of restructuring county government and of creating a perception and an understanding on the part of constituents that adequate or improved efficiency in service delivery will result from an alternative structure. This requires that the administrative mec'hanisms be changed while the public continues to receive satisfactory public services. Can this be done?

\section{Referendum On County Government Reform Act of 1988:}

\section{A Litmus Test}

In August, 1988 the Mississippi Legislature met in special session for th sole purpose of addressing county government reform. At the end of the week long session the legislature passed and Governor Ray Mabus signed the County Government Reform Act of 1988 . This act specified that each county must vote on the change in form of government from the traditional "beat system" to the "unit system" in the general election of November, 1988.

While a number of strong provisions proposed during the session fell victim to heavy opposition from the Mississippi Association of Supervisors, the County Government Reform Act of 1988 as placed before the people represented a significant litmus test of voter's desire for reform of county government. 
In the county-by-county referendum the voters of 47 of the state's 82 counties supported conversion from the "beat system" to the "unit system." The composite vote statewide in favor of the "unit system" was $62 \% ; 38 \%$ voted to remain under the "beat system." On the surface, this would appear to bode well for the future of reform of county government. Further analysis, however, tends to confirm the embedded resistance to reform of rural citizens who feel most affected by county government.

\section{Precinct-Based Analysis of Referendum}

A sample of 38 counties was drawn from the 82 counties statewide. These counties represent all areas of the state geographically and include a range from the most populated to the least populated. Included in these counties were 1064 voting precincts. County precinct maps were used to establish precinct location. Precincts were placed in two general categories each with a sub-category facilitating further analysis. These categories are defined as follows:

Rural

Rural Village

Municipal

Municipal/Rural
Precincts lying entirely outside of any incorporated municipality of 1,000 or more people (Note: These precincts may contain with them some very small rural villages as defined in the "Rural Village" sub-category).

Precincts containing a very small incorporated municipality which provides only a limited range of municipal services (Population of less than 1,000 ).

Precincts lying entirely within an incorporated municipality of 1,000 or more people.

Precincts adjacent to or overlapping a larger incorporated municipality (1,000 in population) which may contain a portion of the municipality.

Table 2 summarizes the placements of precincts into these categories and related sub-categories. 


\section{Table 2. Number and Percentage of Precents by Category and Sub-Category}

\begin{tabular}{lrr}
\hline \hline & Number & $\%$ \\
\hline RURAL & $\frac{604}{508}$ & $\frac{56.7}{47.7}$ \\
Rural - Open & 96 & 9.0 \\
Rural Village & $\underline{460}$ & $\underline{43.3}$ \\
MUNICIPAL & 395 & 37.1 \\
Municipal & 65 & 6.1 \\
Municipal/Rural & 1064 & 100.0 \\
$\quad$ TOTALS & &
\end{tabular}

Categorized precincts were further examined to determined whether they voted for or against conversion to the "Unit System." Using this process, the data clearly revealed that the assumptions made earlier in the study concerning rural resistance to change were verified. Table 3 illustrates these findings.

Table 3. Cross Tabulation of Precinct Category by Vote For or Aganist the Unit System

\begin{tabular}{lccccc}
\hline \hline & For & $\%$ & Against & $\%$ & Total \\
\hline Rural & 213 & 34.3 & 391 & 88.2 & 604 \\
Muni ipal & 408 & 65.7 & 52 & 11.8 & 460 \\
\cline { 2 - 6 } & 621 & 100.0 & 443 & 100.0 & 1064 \\
\hline \multirow{2}{*}{ Phi $=.54$} & & & & \multicolumn{2}{c}{$\mathrm{X}^{2}$ significant at .001 }
\end{tabular}

Table 3 reveals that of the 604 precincts in the "Rural" category, 391 had a majority vote against conversion to the allegedly more progressive "unit system." Of the 460 "municipal" precincts, (shown in table 3 ), 408, a majority, voted in favor of the "unit system." Further, of the 443 precincts 
voting against the "unit system" $88.2 \%$ were rural while conversely, $65.7 \%$ of the 621 precincts voting in favor of conversion to the "unit system" were municipal. The Phi coefficient of .54 is evidence of a strong association between the two cross-tabulated variables and $\mathrm{X}^{2}$ reveals a significance at the .001 level.

Since the "unit system" was, for years and more so during the prereferendum campaign, labeled as "progressive" by its proponents, including Governor Mabus, these findings may be interpreted as steadfast resistance to this particular change by rural residents in Mississippi.

Two explanations are offered for this interpretation. First, municipalities are part of the counties in which they are located, and municipal residents pay property taxes to the county as well as to the municipality, but traditionally these residents expected and received few, if any, direct services from the county. Thus, they are compelled to demand from counties the efficiency promised by county government reform, and they do so without regard to the impact on service delivery. Second, nonmunicipal residents hold fast to the desire to elect all county officials, and they expect these officials to be directly accountable to them for service delivery. Non-municipal voters found it unacceptable that supervisors in counties voting for the "unit system" would be removed from the day-today delivery of services and that their responsibilities would be placed in the hands of an appointed county executive. Non-municipal voters were obviously not persuaded by "unit system" proponents' claims of greater

\section{Table 4. Vote For or Against the Unit System By Precinct Sub-Categories}

\begin{tabular}{cccccc}
\hline \hline & $\begin{array}{c}\text { For } \\
\text { Unit } \\
\text { System }\end{array}$ & $\begin{array}{c}\text { For } \\
\text { For }\end{array}$ & $\begin{array}{c}\text { Against } \\
\text { Unit } \\
\text { System }\end{array}$ & $\begin{array}{c}\text { \% } \\
\text { Against }\end{array}$ & $\underline{\underline{\text { Total }}}$ \\
Rural Village & 37 & 44.6 & 59 & 75.6 & 96 \\
Municipal/Rural $\underline{46}$ & $\underline{55.4}$ & $\underline{19}$ & $\underline{24.4}$ & $\underline{65}$ \\
& 83 & 100.0 & 78 & 100.0 & 161 \\
\hline
\end{tabular}

$\mathrm{Phi}=.32$ 
efficiency and accountability for that form of government. Thus, it appears that the local government unit perceived by the voters to be the primary service deliverer was the key element in determining voter behavior on the question of county government reform.

This fact may be underscored by an examination of the two subcategories in Table 4.

Lacking resources to provide a normal range of municipal services, rural villages must depend on counties for their provision. Thus, it is not surprising that 59 of 96 "rural village" precincts opposed the "unit system" or that of the 78 precincts which were against the "unit system" in these sub-categories $75.6 \%$ of them were in the "rural village" category. Those precincts adjacent to or partially overlapping larger municipalities having full service delivery capabilities exhibited majority support for conversion to the "unit system." An acceptably high level of association between these two variables is demonstrated by a Phi coefficient of .32. Phi findings are significant $\left(\mathrm{X}^{2}\right)$ at the .001 level. This is further evidence of rural voter resistance to arguments supporting purported "progressive" change and support for traditional means of service delivery.

\section{Conclusion}

These findings, while not altogether unexpected, must be of concern to those who would advocate counties as a vehicle for reform in a rural state. This is particularly distressing given that counties are the units of local government whose jurisdiction cover the entire territory of a state. An immediate question which comes to mind relates to the degree of thoroughness in which the "unit system" will actually be implemented by those nembers of boards of supervisors who felt that change was forced upon hem. Of a more general nature, what should be the strategies of those wishing to pursue efficiency and effectiveness in county government to make counties key elements in rural development efforts?

It is possible that answers may be found in a "model counties" approach and in a generalized capacity-building efforts. The former approach involves targeting willing "unit system" counties for implementation of a comprehensive array of more modern management functions. The latter approach entails attempting to gain broad acceptance by counties, whether in the "beat system" or "unit system," of various management innovations in hopes that success in this regard will reduce fear of change. In rural states, like Mississippi, a means must be found for counties not to have reform thrust upon them but to initiate reform in their own terms. 


\section{References}

Blair, George S., 1986. Government at the Grass-Roots. Pacific Palisades, California: Palisades Publishing.

Blau, Joseph L., 1954. Social Theories of Jacksonian Democracy. New York: The Liberal Arts Press.

Grant, Daniel R. and H. C. Nixon, 1968. State and Local Governments in America Boston: Allyn and Bacon, Inc.

Hansen, Susan B., 1978. "Linkage Models, Issues, and Community Politics." American Politics Quarterly. 6: 3-28.

Kasarda, John D. and Morris Janowitz, 1974. "Community Attachment in Mass Society." American Sociological Review. 39: 328-39.

Marando, Vincent L. and Robert D. Thomas, 1977. The Forgotten Governments: County Commissioners as Policy Makers. Gainesville: University Presses of Florida.

Morgan, David R., 1973. "Political Linkage and Public Policy: Attudinal Congruence Between Citizens and Officials." The Western Political Quarterly. 26: 209-23.

Prewitt, Kenneth, 1970. "Political Ambitions, Volunteerism, and Electoral Accountability." The American Political Science Review. 64: 5-17.

Reagan, Michael, 1968. "Policy Issues: The Interaction of Substance and Process." Polity. 1: 35-51.

Redfield, Robert, 1955. The Little Community: Viewpoints for the Study of a Human Whole. Chicago: The University of Chicago Press.

Schlesinger, Arthur M., 1953. The Age of Jackson. Boston: Little, Brown and Company.

Verba, R. and N. H. Nie, 1972. Participation in America: Political Democracy and Social Equality. New York: Harper and Row.

Wiseman, Martin, 1986. The Characteristics of Linkage Between Rural Communities and Public Policy and the Effects of Racial Differences. Unpublished Doctoral Dissertation, Mississippi State University. 